University of Michigan Law School

University of Michigan Law School Scholarship Repository

\title{
Tax Stories and Tax Histories: Is There a Role for History in Shaping Tax Law?
}

\author{
Reuven S. Avi-Yonah \\ University of Michigan Law School, aviyonah@umich.edu
}

Available at: https://repository.law.umich.edu/reviews/1

Follow this and additional works at: https://repository.law.umich.edu/reviews

Part of the Courts Commons, and the Tax Law Commons

\section{Recommended Citation}

Avi-Yonah, Reuven S. "Tax Stories and Tax Histories: Is There a Role for History in Shaping Tax Law?" Mich. L. Rev. 101, no. 6 (2003): 2227-37.

This Review is brought to you for free and open access by the Faculty Scholarship at University of Michigan Law School Scholarship Repository. It has been accepted for inclusion in Reviews by an authorized administrator of University of Michigan Law School Scholarship Repository. For more information, please contact mlaw.repository@umich.edu. 


\title{
TAX STORIES AND TAX HISTORIES: IS THERE A ROLE FOR HISTORY IN SHAPING TAX LAW?
}

\author{
Reuven S. Avi-Yonah*
}

TAX STORIES: AN IN-DEPTH LOOK AT TEN LeAding FEDERAL InCOME TAX CASES. Edited by Paul L. Caron. New York: Foundation Press. 2003. Pp. 375. \$18.95.

"Those who do not learn from history are doomed to repeat it"

-George Santayana

"History repeats itself: The first time as tragedy, the second as farce"

-Karl Marx

The teaching of law is usually rather ahistorical. Teachers commonly focus on current doctrine and policy debates, discarding on the "garbage pile of history" any law that has been repealed or superseded. And yet, much of law teaching is still based on reading cases. And cases are by definition historical artifacts - they arise from a specific time and place, and reflect a frequently long-gone historical context. Thus, it is hard to imagine a modern law course completely devoid of history, even if the history gets short shrift. A constitutional law course, for example, will likely include some discussion of Marbury v. Madison, ${ }^{1}$ but it is unlikely that the teacher will have time to discuss the historical origins of the case in the conflict between Federalists and Jeffersonians at any length.

Tax Stories, edited by Paul L. Caron, ${ }^{2}$ is intended to be the first of a series that will remedy this lack of historical data. Each volume in the series will discuss approximately ten leading cases that are typically covered in major law school courses, and is intended to discuss them in depth and in great historical detail (pp. 1-3). Through this process, which the editor dubs "archaeology," students will learn in detail the background to some of the most important cases they discuss in class. The current volume on tax is scheduled to be followed

* Irwin I. Cohn Professor of Law, University of Michigan. B.A. 1983, Hebrew University; Ph.D. (History) 1986, Harvard; J.D. 1989, Harvard. - Ed. I would like to thank Marjorie Kornhauser, Assaf Likhovski, and Kyle Logue for their very helpful comments on an earlier version.

1. 5 U.S. (1 Cranch) 137,178 (1803).

2. Charles Hartsock Professor of Law, University of Cincinnati College of Law. 
in 2003 by volumes on constitutional law, property, and torts, with others to follow. ${ }^{3}$

This effort represents an admirable attempt to provide students with more in-depth information than they can typically obtain in the course of a classroom discussion focused on current doctrine. The tax volume is well executed; the chapters were written by some of this country's leading tax academics, and they are a pleasure to read. And yet, one is left with a certain feeling of dissatisfaction, because many of the chapters ultimately contain much more discussion of current doctrine than historical background. ${ }^{4}$ It is as if an overwhelming pull toward the present exerted its force on some of the authors, who are, after all, tax professors and (mostly) not historians by training. ${ }^{5}$ But the focus on current doctrine, while understandable, means that the book misses some of the opportunity to add value beyond what is found in, for example, Chirelstein's classic tax manual for students. ${ }^{6}$

This Review is divided into three parts. Part I surveys the chapters of Tax Stories and evaluates their contribution to classroom learning. Part II takes a more critical approach, focusing on some missed opportunities. Part III tries to extend the discussion more broadly into an evaluation of the proper role of history in teaching tax (and perhaps other legal areas as well).

\section{TAX STORIES}

Tax Stories covers ten Supreme Court tax cases: Commissioner v. Glenshaw Glass (definition of income); ${ }^{7}$ Eisner v. Macomber (realization), ${ }^{8}$ United States $v$. Kirby Lumber (cancellation of indebtedness); ${ }^{9}$ Unites States $v$. Davis (property transfers upon divorce) ${ }^{10}$ Welch $v$.

3. See Constitutional LAw Stories (Michael C. Dorf ed., forthcoming 2003); PROPERTY STORIES (Gerald Korngold \& Andrew P. Morriss eds., forthcoming 2003); TORTS STORIES (Robert L. Rabin \& Stephen D. Sugarman eds., forthcoming 2003).

4. Of course, in a book intended for students, current doctrine must be discussed, but that is not the only aim of the book.

5. This is even true for some chapters, like Pat Cain's discussion of Lucas v. Earl, 281 U.S. 111 (1930), that are a veritable treasure trove of historical information; the doctrine ultimately prevails, as is evident in the title. Pp. 275-312 (the title of the chapter is: The Story of Earl: How Echoes (and Metaphors) from the Past Continue to Shape the Assignment of Income Doctrine). Other chapters, however, are more balanced. See, e.g., pp. 53-96 (Marjorie E Kornhauser's chapter on Eisner v. Macomber, 252 U.S. 189 (1920)).

6. Marvin Chirelstein, Federal InCOMe Taxation (9th ed. 2002) - the book that has introduced generations of students to tax law. In fact, it is so good that in the bad old days (circa 1986) its existence was hidden from students lest they understand too well where the teacher was headed.

7. Pp. 15-52 (covering Comm'r v. Glenshaw Glass, 348 U.S. 426 (1955)).

8. Pp. 53-96 (covering Eisner v. Macomber, 252 U.S. 189 (1920)).

9. Pp. 97-130 (covering United States v. Kirby Lumber, 284 U.S. 1 (1931)).

10. Pp. 131-54 (covering United States v. Davis, 370 U.S. 65 (1962)). 
Helvering (ordinary and necessary business expenses) $;{ }^{11}$ INDOPCO v. Commissioner (capitalization) $;{ }^{12}$ Crane $v$. Commissioner (inclusion of debt in basis) ${ }^{13}$ Schlude $v$. Commissioner (distinction between tax and book accounting); $;^{14}$ Lucas $v$. Earl (assignment of income) $;^{15}$ and Knetsch $v$. United States (tax arbitrage).${ }^{16}$ All of these cases are familiar to any student who has taken the basic tax course, and they are well chosen in terms of their importance to understanding our current tax law. ${ }^{17}$

For each case, the same order is followed: First, the author discusses the background to the decision; then he or she describes the case and its prior proceedings before reaching the Supreme Court; then the author discusses the Supreme Court proceedings, including the petition for certiorari, the briefs, and the Supreme Court's opinion(s); then he or she describes the immediate impact of the decision; and finally the author discusses the continuing importance of the decision today. ${ }^{18}$ The result is a thorough examination of the case and its ramifications, which can definitely enhance the knowledge and understanding of students.

It may be asked whether it is worthwhile for students to spend significant time (the chapters are between twenty and forty pages each) to examine a single decision. And yet, examining such important cases in depth can yield significant insights. For example, it is hard to understand modern tax shelters without studying Crane, and Knetsch is a key to understanding the judicial response. ${ }^{19}$

As "stories," some of the cases are more interesting than others. It is hard to tell much of a story about corporate cases like Kirby Lumber or INDOPCO, although in the former case Deborah Schenk does try to bring John Henry Kirby to life (p. 98). In other chapters, however, like Patricia Cain's treatment of Lucas v. Earl, the main protagonist (Guy C. Earl, an important San Francisco lawyer) is

11. Pp. 155-82 (covering Welch v. Helvering, 290 U.S. 111 (1933)).

12. Pp. 183-206 (covering INDOPCO v. Comm'r, 503 U.S. 79 (1992)).

13. Pp. 207-58 (covering Crane v. Comm'r, 331 U.S. 1 (1947)).

14. Pp. 259-74 (covering Schlude v. Comm'r, 372 U.S. 128 (1963)).

15. Pp. 275-312 (covering Lucas v. Earl, 281 U.S. 111 (1930)).

16. Pp. 313-70 (covering Knetsch v. United States, 364 U.S. 361 (1960)).

17. The one case one can quibble about is Schlude, which is not frequently taught, but I agree it should be included in light of current discussions of the proper relationship between tax and financial accounting.

18. TAX STORIES, passim.

19. See pp. 207-58, 313-70. Of course, the specific shelters that arose from these cases have been largely shut down by the enactment of $\$ \$ 469$ and 264, but the cases are invaluable to understand both why these sections were enacted and the growth of the tax shelter movement (arguably the most important phenomenon in current tax practice) in general. 
vividly recreated. ${ }^{20}$ In some instances one wishes for a different choice of case: David Zarin, the inveterate gambler who lost a fortune in Atlantic City casinos, is a more interesting character (and the case a more fascinating case) than the Kirby Lumber corporation, ${ }^{21}$ and the story of Walter Kresge's prenuptial agreement with Farid-esSultaneh $^{22}$ would make for more interesting reading than the humdrum divorce in Davis (pp. 131-54). But the editor decided to focus on Supreme Court cases, and that is an understandable choice. ${ }^{23}$ The discussion of INDOPCO, the most current case in the book, necessarily is largely doctrinal, but it does raise the interesting issue of why Justice Blackmun, the best-trained tax lawyer in the history of the Supreme Court, so consistently reached bad results in tax cases. ${ }^{24}$

Occasionally, part of the historical background seems missing: it is hard to understand the Eisner v. Macomber definition of income as deriving from "capital or labor or both combined" (discussed in the chapter on Glenshaw Glass (pp. 38-39)) without knowing something about its origins in the U.K. schedular system of taxation (which is not mentioned). ${ }^{25}$ The result is a misguided conclusion that the comprehensive American definition of income (embodied in Glenshaw Glass) is the only sensible way to construct an income tax system, which is

20. Pp. 280-86 - a magnificent piece of historical sleuthing, somewhat obscured by the overall emphasis of the chapter on current doctrine. Cain also does a good job in bringing to life Mabel Willebrandt, the main government litigator in the case. Pp. 294-99.

21. See Zarin v. Comm'r, 92 T.C. 1084 (1989), rev'd, 916 F.2d 110 (3d Cir. 1990); Daniel Shaviro, The Man Who Lost Too Much: Zarin v. Commissioner and the Measurement of Taxable Consumption, 45 TAX L. REV. 215 (1990). Zarin is discussed briefly in pp. 123-24, but one wishes for more.

22. Farid-es-Sultaneh v. Comm'r, 160 F.2d 812 (2d Cir. 1947), involved a prenuptial transfer of stock by Kresge (one of the richest men in the U.S.) to his intended bride, an Egyptian belly dancer, at a time that "Mr. Kresge was married to another person," p. 152 again one wishes for more.

23. But perhaps a misleading one - the students might be left with the impression that Supreme Court cases are a central source of tax law, whereas in practice they are far less important than the IRS regulations. In fact, some of the cases mentioned in the book (like INDOPCO, pp. 183-206) were immediately followed by IRS rulings that effectively reversed some of their implications (e.g., that advertising expenses must be capitalized). Compare INDOPCO, 503 U.S. 49 (1992), with Rev. Rul. 92-80, 1992-2 C.B. 57 (1992). This example of how the supposed hierarchy of sources can be reversed is extensively explored by Bankman, p. 202.

24. See p. 188. For a more positive evaluation of Blackmun's tax cases see Robert A. Green, Justice Blackmun's Federal Tax Jurisprudence, 26 HASTINGS CONST, L.Q. 109 (1998). The only other Justice with significant tax expertise was Robert Jackson, who likewise did not distinguish himself greatly in his Supreme Court tax opinions. See Kirk J. Stark, The Unfulfilled Tax Legacy of Justice Robert H. Jackson, 54 TAX L. REV. 171 (2001).

25. See Marjorie E. Kornhauser, The Origins of Capital Gains Taxation: What's Law Got To Do With It?, 39 Sw. L.J. 869 (1985) [hereinafter Kornhauser, Origins]. The U.K. taxes different types of income (e.g., wages, investment income, capital gains) separately with a different rate for each "schedule." 
not true here (see capital gains) and certainly not overseas. ${ }^{26} \mathrm{I}$ also would have liked to see some discussion of whether the Court's refusal after Macomber to decide tax cases on constitutional grounds is a good policy (again, other countries do it differently). ${ }^{27}$ But generally, the authors tend to get their history right, emphasizing, for example, the very different rate schedule that applied under Knetsch (p. 314), or the origins of Macomber in the Lochner era. ${ }^{28}$ On the other hand, many chapters do tend to emphasize the present doctrinal implications more than the past. That is understandable since most of the authors (Marjorie Kornhauser excluded) are not historians, but it does make some chapters read more like extensions of Chirelstein than in-depth discussions of historical artifacts. ${ }^{29}$

\section{SOME MISSED OPPORTUNITIES}

All of the above are minor quibbles with an otherwise excellent book. There are also, however, some missed opportunities in the volume as a whole.

The first one is missing cases. I would not omit any of the chapters, and I understand the focus only on Supreme Court cases. ${ }^{30}$ But there are two cases that I would definitely like to see included in a future second edition. The first is Gregory v. Helvering, the most frequently cited tax case ever. ${ }^{31}$ Presumably, it was omitted because it is a corpo-

26. Professor Dodge calls the comprehensive definition the "modern concept of gross income," pp. 15, 51 (" 'Modern' means free of the clutter and distractions inherited from the nineteenth century and early twentieth century."). It can be argued, however, that the contemporary trend is to emphasize the schedular nature of income and, in particular, to tax income from capital more lightly than labor income because of its higher mobility and elasticity (responsiveness to taxation). See Eric M. Zolt, The Uneasy Case for Uniform Taxation, 16 VA. TAX REV. 39 (1996). This is another example of the tax law evolving in a circular rather than a linear fashion. See infra notes $48-52$ and accompanying text.

27. See, for example, the practice in Germany, where the Bundesverfassungsgericht (the Supreme Constitutional Court) invalidated the lower taxation of interest compared to wages on equal protection grounds - an unimaginable result here. One consequence of the Supreme Court staying away from deciding tax cases on constitutional grounds has been to marginalize tax by divorcing it from the major debates of modern American life, leaving the students with the impression that it is a dry, technical field rather than a topic at the heart of the relationship between citizens and the State.

28. Pp. 73-76. Not surprisingly this is the best chapter in the book from a historian's perspective, as the author is well known for her pioneering work on tax history. See, e.g., Kornhauser, Origins, supra note 25.

29. Of course, I don't mean that the current implications of each case should not be discussed (after all this is not a pure history book), but rather that in some of the chapters there is little history and a lot of doctrine.

30. It is possible of course that the book had to include only ten cases. In that case, I would have dropped Schlude (too technical) and INDOPCO (too recent) in favor of Gregory v. Helvering, 69 F.2d 809 (2d Cir. 1934), affd, 293 U.S. 465 (1935), and Corn Products Ref. Co. v. Comm'r, 350 U.S. 46 (1955).

31. 293 U.S. 465 (1935). The case is briefly discussed in the Knetsch chapter, pp. 320-324,

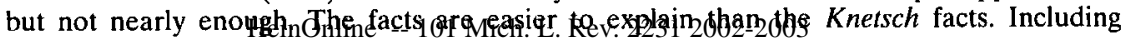


rate tax case that is frequently not taught in the basic tax course (though it should be). But Eisner v. Macomber is also a corporate case, and a more difficult one to explain to students. ${ }^{32}$ Including Gregory would have enabled the author to discuss in depth the wonderfully quotable Learned Hand and Supreme Court opinions (and the crucial difference between them).$^{33}$ It would also have introduced students to the joys of substance-over-form analysis, one of the glories of the U.S. tax system, and the aspect of it that most attracts many students to tax (myself included). Finally, it would have shown students that notwithstanding the frequently quoted Hand language about the payment of taxes not being a patriotic duty, not everything goes in the tax field an important lesson in this era of tax shelters.

The other case I would like to see included is Corn Products Refining Co. v. Commissioner ${ }^{34}$ (and its reversal in Arkansas Best Corp. v. Commissioner) ${ }^{35}$ Given the importance of the capital gains preference in today's rate environment, I would imagine that these cases are covered in every basic tax course. In addition, Arkansas Best is an opportunity to discuss one of Justice Marshall's tax opinions and if Blackmun was one of the worst tax jurists ever to sit on the Court, surely Marshall was among the best (he did not know much about tax, but had a lot of common sense).$^{36}$

The inclusion of these two cases would go far toward remedying another flaw in the book. As Paul Caron notes in his introduction, Tax Stories paints a very bleak picture of the quality of Supreme Court tax jurisprudence. ${ }^{37}$ The cases are either decided wrongly (e.g., Welch, Davis, Schlude) or they have terrible unforeseen (but perhaps

Gregory would also have emphasized the fact that a lot of important early tax cases involved women (e.g., Mrs. Gregory, Mrs. Crane, Mrs. Macomber).

32. To understand the Brandeis dissent in Macomber, one needs to delve into the intricacies of corporate finance; to understand Gregory one only needs to know the basic facts about dividend taxation. Besides, the Gregory opinion is important and cited for its general outcome and reasoning, not the specific facts.

33. The Hand opinion is about Congressional intent and legislative purpose, the Supreme Court opinion is about the taxpayer's motivation. See Gregory, 69 F.2d at 810-11, aff'd, 293 U.S. at 469.

34. 350 U.S. 46 (1955).

35. 485 U.S. 212 (1988).

36. See, for example, Justice Marshall's opinions in Cottage Sav. Ass'n v. Comm'r, 499 U.S. 554 (1991); United States v. Goodyear Tire \& Rubber Co. v. Comm'r, 493 U.S. 132 (1989); Arkansas Best Corp., 485 U.S. 212 (1988); and Gen. Dynamics Corp. v. United States, 481 US 239 (1987) - invariably displaying a preference for the administrable outcome over the economically "correct" result, whereas Blackmun invariably preferred the latter over the former. See, e.g., Idaho Power Co. v. Comm'r, 418 U.S. 1 (1974). See generally Stephen B. Cohen, Thurgood Marshall: Tax Lawyer, 80 GEO. L.J. 2011 (1992).

37. Pp. 12-13 ("[N]one of the opinions (and their authors) escape unscathed." (footnote omitted)). 
foreseeable) consequences (Crane, INDOPCO, Earl)..$^{38}$ Only a few cases seem clearly correct, but even they involve flawed reasoning (Glenshaw Glass, Macomber, Kirby Lumber). ${ }^{39}$ Knetsch emerges as the only decent opinion, but even there one faces the question whether retroactively closing the loophole was appropriate.$^{40}$ If the book had included Gregory and Arkansas Best, it would seem more balanced, especially if the chapters also covered other corporate opinions from the 1930s (e.g., the continuity of interest cases) and other Marshall opinions. ${ }^{41}$ "[S]poradic omnipotence" (Justice Jackson's phrase for the Court's role in tax cases) would not seem so bad. $^{42}$

The most important flaw in the book from my perspective, however, is the ordering of the chapters. They are ordered in the way the issues are usually presented in the basic tax course, and not in their proper chronological sequence. The resulting absurdity is seen right at the beginning: Glenshaw Glass, which effectively overruled Macomber, is placed before it because students learn the definition of income before they learn about realization. But this involves a huge lost opportunity to sensitize students to the historical development of the U.S. tax system. If a teacher uses the book as a supplement to reading the cases in class, she can assign them out of order. But if the book were arranged in the correct chronological order, at least the students would have been made aware that Macomber was followed by Glenshaw, and not the other way round.$^{43}$ And if they happened to read the whole book in order, they would have gotten a glimpse of the development of the U.S. tax system over time. As a historian and the son of an archaeologist, I can say that this book as currently arranged is neither tax history nor "tax archaeology"; no historian or archaeologist would jumble their chronology in this fashion.

This leads me to my final topic: What is the proper role of history in studying tax law? The ahistorical ordering of Tax Stories reflects most tax teachers' training and emphasis on current doctrine at the

38. See INDOPCO v. Comm'r, 503 U.S. 79 (1992); Schulde v. Comm'r, 372 U.S. 128 (1963); United States v. Davis, 370 U.S. 65 (1962); Crane v. Comm'r 331 U.S. 1 (1947); Welch v. Helvering, 290 U.S. 111 (1933); Lucas v. Earl, 281 U.S. 111 (1930).

39. See Comm'r v. Glenshaw Glass Co., 348 U.S. 426 (1955); United States v. Kirby Lumber Co., 284 U.S. 1 (1931); Eisner v. Macomber, 252 U.S. 189 (1920).

40. See p. 330 (discussing the effective date provision in the legislation aimed at the Knetsch loophole).

41. See, for example, the Marshall opinions in Cottage Sav. Ass'n v. Comm'r, 499 U.S. 554 (1991); United States v. Goodyear Tire \& Rubber Co. v. Comm'r, 493 U.S. 132 (1989); Arkansas Best Corp. v. Comm'r, 485 U.S. 212 (1988); Gen. Dynamics Corp. v. United States, 481 US 239 (1987).

42. See Arrowsmith v. Comm'r, 344 U.S. 6, 12 (1952) (Jackson, J., dissenting).

43. Most students "don't know much about history" and cannot be expected to catch this by themselves. 
expense of history. But this emphasis comes at a cost, even for understanding current doctrine, which I will explain below.

\section{A ROLE FOR HISTORY?}

An exasperating feature of many current tax casebooks is that they omit any case that is no longer current law. ${ }^{44}$ The problem with this method, of course, is that to understand current law you need to know what was the problem that led to its enactment. Frequently, the best way to understand that problem is to read the cases that were reversed by the new law. ${ }^{45}$ In this narrow way, knowing history is essential to understanding current doctrine, and the best way to understand current doctrine is to teach it in chronological order, with each enactment plugging loopholes left by its predecessor. ${ }^{46}$

But history has a broader and more important role to play in understanding taxation. If you listen to many academic expositions of tax law, you might think that taxation is grounded in the exact sciences (or at least in economics), and therefore that it progresses over time as scientific knowledge improves, tax law gets better. From this "Whiggish" perspective, it is indeed unimportant to study anything but current doctrine, just like a course in physics will spend little time on Aristotle or Ptolemy. ${ }^{47}$

The actual evolution of the tax law, however, has been nothing like the linear progression suggested by this view. ${ }^{48}$ In fact, the actual development of tax law has tended much more to go in cycles, with different ideas being born, dying and then being re-born. For example, the current rage to integrate corporate and shareholder taxes by exempting dividends from income ${ }^{49}$ is a return to pre-1936

44. Perhaps with the exception of the cases in Tax Stories, many of which have been overturned by Congress in whole or in part (e.g., Macomber, Davis, Earl). But even cases that are wholly obsolete - like Poe v. Seaborn, 282 U.S. 101 (1930) - are indispensable to understanding how we got to current doctrine - in this case, to the joint return.

45. For example, to understand why section 306 (concerning preferred stock bailouts) was enacted, one must read Chamberlin v. Comm'r, 207 F.2d 462 (6th Cir. 1953), which has been omitted, for example, from PAUL R. MCDANIEL ET AL., FEDERAL INCOME TAXATION OF CORPORATIONS 315 (2nd ed, 1999). A short blurb is not enough; the students will not remember it.

46. The six antideferral regimes in the international tax course provide a particularly good example of this. See REUVEN S. AVI-YONAH, U.S. INTERNATIONAL TAXATION 188252 (2002).

47. See Herbert Butterfield, The Whig InTERPREtation OF History (1965).

48. Kyle Logue, Legal Transitions, Rational Expectations, and Legal Progress, $14 \mathrm{~J}$. CONTEMP. LEG. ISSUES (forthcoming 2003).

49. For President Bush's proposal, see the Jobs and Growth Tax Act of 2003, H.R. 2, 108th Cong. \& 201 (2003) Yentline -- 101 Mich. L. Rev. 2234 2002-2003 
law, ${ }^{50}$ and the current treatment of capital gains ${ }^{51}$ is a return to pre-1986 law..$^{52}$

Tax academics may dismiss this as "just politics" interfering with the desirable progress toward the ideal tax system. But of course, at its heart taxation is all about politics - it is about the relationship between citizens and the state, and about the proper size of the public sector. These are properly the most contested political issues, which come up in every election. To pretend that there is a pure tax science that constantly progresses and that can be separated from these questions is to ignore reality.

An important example can be given of the cost to tax policy of ignoring history and the political perspective: the proper role of progressive taxation, or to put it otherwise, why the rich should be taxed more than the poor. ${ }^{53}$ Current doctrine offers two answers to this question, but for me they are both unsatisfactory. Optimal tax theory, which is based on economic analysis, indicates that progressive taxation is justified given certain plausible assumptions about the declining marginal utility of money, but only if one adopts certain social welfare functions. ${ }^{54}$ Ultimately, if one disagrees with the social welfare function proposed to justify redistribution, optimal tax theory cannot show that progressivity is required..$^{55}$ Alternatively, current doctrine attempts to justify progressivity and redistribution on vertical equity grounds (although optimal tax theorists reject equity has having an independent normative value apart from utility). ${ }^{56}$ However, the degree of progressivity that can be defended on equity grounds can be quite limited, as shown by Ed McCaffery's recent book, Fair, Not Flat. ${ }^{57}$ This otherwise excellent defense of progressivity is about whether a consumption-based tax should be progressive. The problem

50. See Steven Bank, Corporate Managers, Agency Costs, and the Rise of Double Taxation, 44 WM. \& MARY L. REV. 167 (2002) [hereinafter Bank, Corporate Managers].

51. I.R.C. $\$ \$ 1,1221$ (2002).

S2. I.R.C. $\$ \$ 1,1221(1985)$.

53. See Reuven S. Avi-Yonah, Why Tax the Rich? Efficiency, Equity and Progressive Taxation, 111 YALE L.J. 1391 (2002) [hereinafter Avi-Yonah, Why Tax the Rich?] (book review).

54. See Joseph Bankman \& Thomas Griffith, Social Welfare and the Rate Structure: $A$ New Look at Progressive Taxation, 75 CAL. L. REV. 1905 (1987).

55. See Lawrence Zelenak \& Kemper Moreland, Can the Graduated Income Tax Survive Optimal Tax Analysis?, 53 TAX L. REV. 51, 90 (1999).

56. See Louis KaPlow \& SteVe Shavell, Fairness Versus Welfare (2002). Compare EDWARD J. MCCAFFERY, FAIR, NOT FLAT: HOW TO MAKE THE TAX SYSTEM BETTER AND SIMPLER (2002), with Louis Kaplow \& Steve Shavell, Fairness versus Welfare, 114 HARV. L. REV. 961 (2001).

57. See MCCAFFery, supra note 56; see also Steven A. Bank, The Progressive Consumption Tax Revisited, 101 MICH. L. REV 2238 (2003) (reviewing MCCAFFERY, supra note $56)$. 
with this debate is that in the case of the truly rich, who consume a minuscule proportion of their income, it makes little difference whether the tax is progressive or not. If Bill Gates consumes a billion dollars a year, the debate is about whether he should be taxed on his consumption at (say) $20 \%$ or $90 \%$. But even the latter rate would not begin to make a dent in his (mostly unrealized) accumulated income.

The fundamental problems with both the optimal tax (economic) and vertical equity (philosophical) approaches to progressivity are that (a) they approach the problem from an individual, not a societal perspective, and (b) they are ahistorical. If, instead, one adopts the view that the core problem is addressing the social distribution of wealth, and realizes that this distribution (as measured by the Gini coefficient) is now as skewed or more skewed toward the super-rich (top 1\%) than in the heyday of the Gilded Age, ${ }^{58}$ it is possible to ask another question: By what tax measures can society's wealth be redistributed from the rich to the poor (i.e., how can the Gini coefficient be reduced)? The first obvious answer is a wealth tax, but if that is impracticable for political or administrative reasons, an income tax that truly reaches income from capital is the second best alternative. Hence, support the estate tax, and any part of the income tax that reaches income from capital. ${ }^{59}$

This was well understood by Henry Simons in $1938^{60}$ and even by Blum and Kalven in $1952,{ }^{61}$ but it is lost knowledge today. Otherwise, it is hard to understand how a self-defined liberal like Professor McCaffery can support repeal of the estate tax and the income tax, to be replaced by a progressive consumption tax. ${ }^{62}$ Adoption of this proposal would bring us most of the way back to 1894 , when the first modern income tax was adopted precisely because Federal excise (consumption) taxes were regressive and the states' personal property tax could not reach intangible forms of wealth for administrative reasons. Hence the income tax, which was (quite correctly) struck down by the Supreme Court as an indirect way of taxing wealth, but re-adopted after the surprising ratification of the Sixteenth Amendment in 1913.

58. See, e.g., Kevin Phillips, WealTh AND Democracy (2002); see also Richard L. Kaplan, Economic Inequality and the Role of Law, 101 MICH L. REV. 1987 (2003) (reviewing PHILLIPS, supra).

59. This includes the corporate tax, which can be justified as a limit on management power in publicly traded entities. See Avi-Yonah, Why Tax the Rich?, supra note 53, for a more elaborate discussion.

60. Henry Simons, Personal InCome Taxation 19 (1938).

61. Walter J. Blum \& Harry Kalven, Jr., The Uneasy Case for Progressive Taxation, 19 U. CHI. L. REV. 417 (1952). 
From this perspective, history has a dual role to play in legal scholarship. First, it can teach us about the reasons we got to where we are now. Those reasons are often forgotten in the midst of current debates. ${ }^{63}$ Second, to the extent that the historical reason is still valid today, history can provide some normative rationale for accepting or rejecting current doctrine. ${ }^{64}$

For example, in the redistribution context, one can still disagree with the argument that redistribution is necessary to preserve the well being of American society, prevent the rich from accumulating too much power, and prevent social unrest and even potential revolution. ${ }^{65}$ One can also argue that the negative incentive effects of too high progressive tax rates preclude a return to the pre-1980 rate structure (top rate of $70 \%$ ). ${ }^{66}$ But whether one argues about the ends or the means, at least then the debate will be couched in its proper political and historical terms, and not diverted to sterile fights about supposedly neutral terms like the social welfare function or vertical equity.

One view of tax scholarship in the last three decades is that it has tried mightily to distance itself from politics and present itself as a neutral science that is based on economic or philosophical principles and hence improves over time. This has led tax scholarship to be divorced from tax reality, which is all about politics, and has left liberal tax scholars weaponless in the face of the relentless assault on progressivity and on the redistributive agenda that has dominated the political scene since Ronald Reagan's election in 1980. It is time for liberal tax scholars to return to their political roots, to make explicit comparisons between the current state of affairs and the period in which the income and estate taxes were first adopted, and to defend redistribution in historical and political terms. A properly done tax history would help achieving this goal. ${ }^{67}$

63. See, for example, Steve Bank's excellent demonstration that tax-free reorganizations originated in the debate about whether capital gains are income. Steven A. Bank, Mergers, Taxes, and Historical Realism, 75 TUL. L. REV. 1 (2000) [hereinafter Bank, Mergers, Taxes, and Historical Realism].

64. Of course, history by itself can never be normatively binding. See Oliver Wendell Holmes, The Path of the Law, 10 HARV. L. REV. 457, 469 (1897).

65. For an elaboration, see Avi-Yonah, Why Tax the Rich?, supra note 53.

66. The incentive effects are not easy to document, but are presumed high at rates above $50 \%$. See Joel Slemrod, Does AtLas Shrug? The ECONOMIC CONSEQuences OF TAXING THE RICH (2000). This still leaves a lot of scope for raising rates, though.

67. Such a history is in fact beginning to materialize - see, for example, TAX JUSTICE (Joseph Thorndike \& Dennis Ventry eds., 2002); Bank, Corporate Managers, supra note 50; Bank, Mergers, Taxes, and Historical Realism, supra note 63; and Kornhauser, Origins, supra note 25 . 